\title{
Juvenile temporal arteritis
}

INSERM

\section{Source}

INSERM. (1999). Orphanet: an online rare disease and orphan drug data base. Juvenile temporal arteritis. ORPHA:26137

Juvenile temporal arteritis (TTA) is an extremely uncommon vasculitis of unknown etiology. Eleven documented cases have been reported in the literature, affecting older children and young adults. In contrast to the classic form of temporal arteritis, it is not a systemic disease nor does it cause local symptoms at the temporal area. The term JTA was coined by Lie and his colleagues, in 1975, when they reported four cases of an otherwise asymptomatic disease presenting with a painless nodule at the temporal region. None of the cases showed evidence of systemic disease or history of trauma to the temporal region. Excisional biopsy of the lesions revealed a non-giant cell granulomatous inflammation of the temporal arteries with eosinophilic infiltration, intimal proliferation and microaneurysmal disruption of the media. JTA has a benign clinical course, is treated by surgical excision and does not recur. 